\title{
Recent advances in understanding idiopathic pulmonary
}

\section{fibrosis [version 1; peer review: 2 approved]}

\author{
Cécile Daccord ${ }^{1,2}$, Toby M. Maher $1,3,4$ \\ ${ }^{1}$ Interstitial Lung Disease Unit, Royal Brompton and Harefield NHS Foundation Trust, London, UK \\ ${ }^{2}$ Respiratory Medicine Department, Lausanne University Hospital, Lausanne, Switzerland \\ ${ }^{3}$ NIHR Respiratory Biomedical Research Unit, Royal Brompton Hospital, London, UK \\ ${ }^{4}$ Fibrosis Research Group, Imperial College, London, UK
}

V1 First published: 31 May 2016, 5(F1000 Faculty Rev):1046

https://doi.org/10.12688/f1000research.8209.1

Latest published: 31 May 2016, 5(F1000 Faculty Rev):1046

https://doi.org/10.12688/f1000research.8209.1

\begin{abstract}
Despite major research efforts leading to the recent approval of pirfenidone and nintedanib, the dismal prognosis of idiopathic pulmonary fibrosis (IPF) remains unchanged. The elaboration of international diagnostic criteria and disease stratification models based on clinical, physiological, radiological, and histopathological features has improved the accuracy of IPF diagnosis and prediction of mortality risk. Nevertheless, given the marked heterogeneity in clinical phenotype and the considerable overlap of IPF with other fibrotic interstitial lung diseases (ILDs), about $10 \%$ of cases of pulmonary fibrosis remain unclassifiable. Moreover, currently available tools fail to detect early IPF, predict the highly variable course of the disease, and assess response to antifibrotic drugs.
\end{abstract}

Recent advances in understanding the multiple interrelated pathogenic pathways underlying IPF have identified various molecular phenotypes resulting from complex interactions among genetic, epigenetic, transcriptional, post-transcriptional, metabolic, and environmental factors. These different disease endotypes appear to confer variable susceptibility to the condition, differing risks of rapid progression, and, possibly, altered responses to therapy. The development and validation of diagnostic and prognostic biomarkers are necessary to enable a more precise and earlier diagnosis of IPF and to improve prediction of future disease behaviour. The availability of approved antifibrotic therapies together with potential new drugs currently under evaluation also highlights the need for biomarkers able to predict and assess treatment responsiveness, thereby allowing individualised treatment based on risk of progression and drug response. This approach of disease stratification and personalised medicine is already used in the routine management of many cancers and provides a potential road map for guiding clinical care in IPF.

\section{Keywords}

idiopathic pulmonary fibrosis, interstitial lung diseases

\section{Open Peer Review}

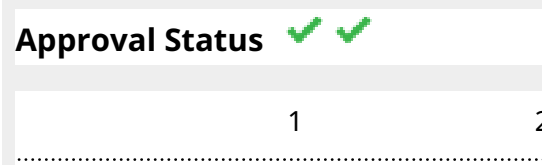

version 1

31 May 2016

Faculty Reviews are review articles written by the prestigious Members of Faculty Opinions. The articles are commissioned and peer reviewed before publication to ensure that the final, published version is comprehensive and accessible. The reviewers who approved the final version are listed with their names and affiliations.

1. Paul W Noble, Cedars Sinai Medical Center, Los Angeles, USA

2. Simon P Hart, Hull York Medical School, Cottingham, UK Any comments on the article can be found at the end of the article. 
Corresponding author: Toby M. Maher (t.maher@rbht.nhs.uk)

Competing interests: Cécile Daccord does not have competing interests to report. Toby Maher has no declarations directly related to this manuscript. He has, however, received industry-academic research funding from GlaxoSmithKline R\&D, UCB, and Novartis and has received consultancy or speakers fees from Apellis, Bayer, Biogen Idec, Boehringer Ingelheim, Dosa, GlaxoSmithKline R\&D, Galapagos, Novartis, ProMetic, Roche, Sanofi-Aventis, and UCB.

Grant information: Cécile Daccord is supported by Ligue Pulmonaire Vaudoise, Service de pneumologie CHUV, and Fonds de perfectionnement CHUV. Toby M Maher is supported by an NIHR Clinician Scientist Fellowship (NIHR Ref: CS-2013-13-017) and receives additional infrastructure support from the Royal Brompton NIHR funded biomedical research unit. The funders had no role in study design, data collection and analysis, decision to publish, or preparation of the manuscript.

Copyright: (c) 2016 Daccord C and Maher TM. This is an open access article distributed under the terms of the Creative Commons Attribution License, which permits unrestricted use, distribution, and reproduction in any medium, provided the original work is properly cited.

How to cite this article: Daccord C and Maher TM. Recent advances in understanding idiopathic pulmonary fibrosis [version 1; peer review: 2 approved] F1000Research 2016, 5(F1000 Faculty Rev):1046 https://doi.org/10.12688/f1000research.8209.1

First published: 31 May 2016, 5(F1000 Faculty Rev):1046 https://doi.org/10.12688/f1000research.8209.1 


\section{Introduction}

Idiopathic pulmonary fibrosis (IPF) is typically introduced as a chronic progressive and inevitably fatal scarring lung disease with a prognosis worse than that of numerous cancers ${ }^{1,2}$. Hopefully, this is now beginning to change. Although the etiology and the pathogenesis of IPF are still incompletely understood, two antifibrotic drugs, pirfenidone and nintedanib, have recently been proven to be effective in slowing disease progression and are now approved as treatments in the United States and Europe ${ }^{3,4}$.

The recent development of affordable, high-throughput -omics technologies has opened the era of systems biology and has enabled the emergence of stratified and personalised medicine. These approaches are becoming routine practice in oncology $y^{5}$ and have enormous potential in offering new insights into the understanding and management of pulmonary diseases ${ }^{6}$, including IPF.

This article aims to provide an overview of recent developments in disentangling the complex interrelated mechanisms involved in the pathogenesis of IPF with a particular focus on those that may lead to improved diagnosis, stratification of disease behaviour, and identification of potential novel therapeutic targets and predictors of response to treatment. Considerations concerning the past, present, and future pharmacotherapy of IPF were addressed in the March 2014 issue of this journal ${ }^{7}$ and will not be discussed in this current review.

\section{Diagnosis}

The current approach to IPF diagnosis was first described in international guidelines published in 2001, which were recently updated. These guidelines define precise diagnostic criteria based on clinical, radiological, and histopathological features ${ }^{8}$ and enshrine the place of multidisciplinary discussion among experienced clinicians, radiologists, and pathologists as the gold standard method for establishing a diagnosis of IPF. Using the current guidelines, in about two-thirds of the cases, a confident diagnosis of IPF can be achieved based on an appropriate clinical history in association with a typical high-resolution computed tomography (HRCT) pattern of usual interstitial pneumonia (UIP) (Figure 1). When clinical and HRCT data are non-diagnostic, surgical lung biopsy (SLB) is recommended to confirm UIP diagnosis histologically (Figure 2). However, SLB carries considerable risks and is often contraindicated in older patients with extensive co-morbidities or in those presenting with advanced lung disease ${ }^{9}$. Thus, even in experienced centres, a diagnosis of unclassifiable interstitial lung disease (ILD) is assigned to about $10 \%$ of patients who present with progressive pulmonary fibrosis ${ }^{10}$.

In a recent study of 117 patients with fibrotic ILDs, bronchoscopic lung cryobiopsy has proven to be safe and effective in providing adequate lung tissue samples, which enabled increased diagnostic confidence in the multidisciplinary diagnosis of $\mathrm{IPF}^{11}$. This minimally invasive technique represents an attractive alternative to SLB and may, pending further studies, be included in the diagnostic algorithm of IPF and other fibrotic ILDs in the near future.

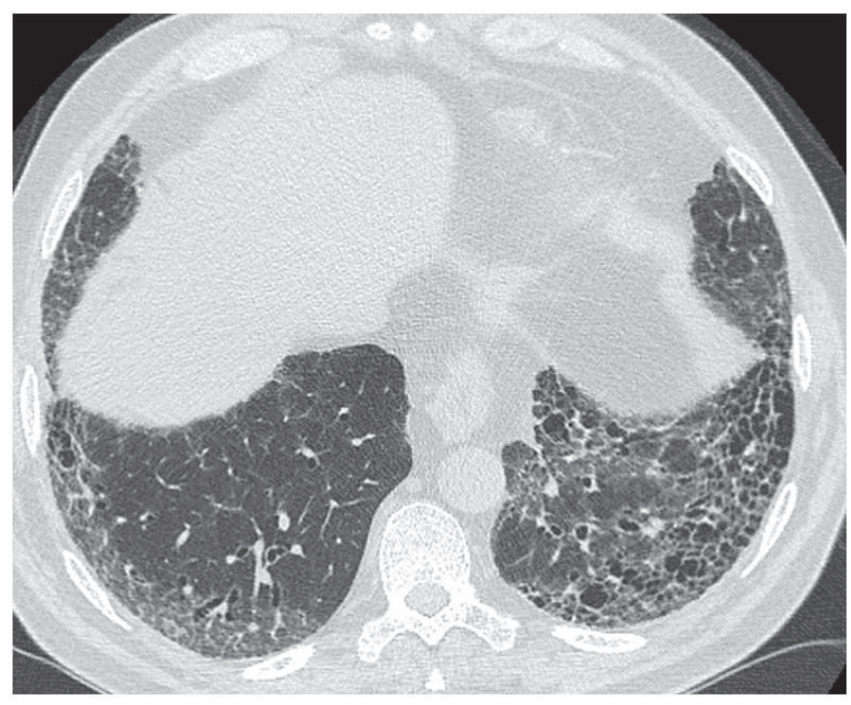

Figure 1. Typical high-resolution computed tomography (HRCT) pattern of usual interstitial pneumonia (UIP). The image shows subpleural and basal predominance of reticular opacities associated with traction bronchiectasis and honeycomb change (clustered cystic airspaces with well-defined thick walls and diameter of $0.3-1.0 \mathrm{~cm})$.

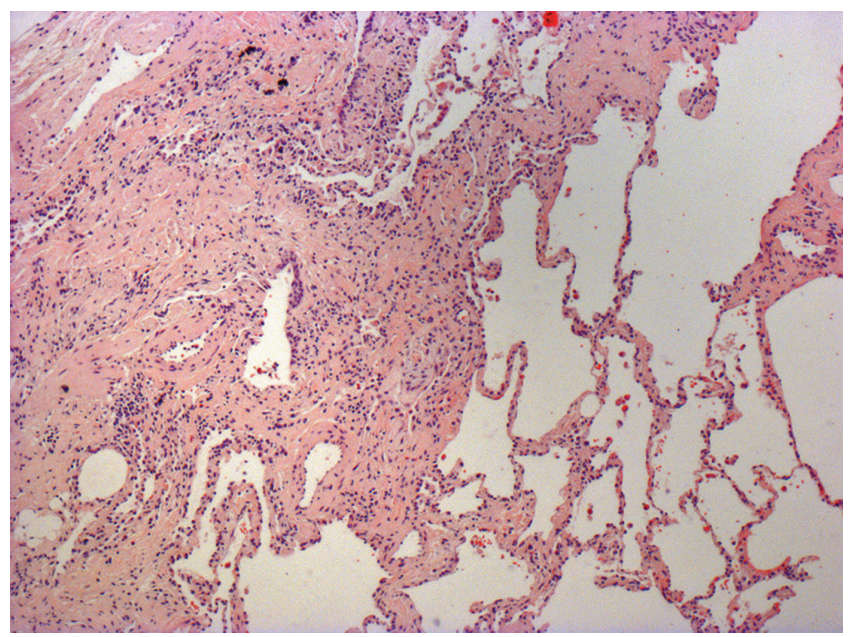

Figure 2. Photomicrograph of biopsy from a 63-year-old man with a multi-disciplinary diagnosis of idiopathic pulmonary fibrosis. The patient shows the typical histopathological features of usual interstitial pneumonia characterised by spatial heterogeneity with areas of subpleural and paraseptal fibrosis and honeycombing changes (cystic airspaces lined by bronchiolar epithelium) alternating with areas of relatively spared lung parenchyma, temporal heterogeneity with admixed areas of active fibrosis with fibroblast foci, extracellular matrix deposition (mainly collagen), and relative mild or absence of inflammatory cell infiltrate together with regions of histologically normal lung tissue. 


\section{Pathogenesis}

The heterogeneity in radiological and histopathological appearances, rate of progression, and treatment response observed in individuals with IPF suggests that fibrosis arises as a consequence of multiple co-activated pathogenic pathways, all of which are influenced by complex interactions between endogenous and environmental factors ${ }^{12}$. This multiple-pathway model probably explains the disappointing results of therapies targeting single receptors or pathways in IPF. Future treatment strategies in IPF are likely to focus on combinations of therapies targeting multiple pathogenic pathways simultaneously, as is currently used in the treatment of many cancers ${ }^{13}$.

Until 15 years ago, the prevailing pathogenic paradigm in IPF was one of chronic inflammation being the precursor to progressive fibrosis. This has shifted over the last decade to a model of abnormal wound healing response driven by persistent or recurrent alveolar epithelial microinjuries (e.g. cigarette smoke, microaspiration, or infection) in individuals rendered susceptible by ageing or genetic predisposition ${ }^{14}$. Multiple studies have shown that alveolar epithelial cell (AEC) apoptosis secondary to injury is followed by extravascular coagulation, immune system activation, and aberrant persistent activation of AECs, even in the absence of the primary stimulus ${ }^{15}$. These cells, in turn, induce the migration and proliferation of local fibroblasts, recruit circulating fibrocytes to areas of injury, and promote differentiation of fibroblasts into myofibroblasts. This results in the formation of myofibroblast foci, the histologic hallmark of UIP, in which persistently activated myofibroblasts secrete excessive amounts of extracellular matrix (ECM) proteins. Disordered deposition and accumulation of ECM components within the interstitium and alveolar spaces lead to established fibrosis with progressive destruction of lung architecture and loss of function.

This pathogenic cascade involves complex cell-cell and cell-matrix interactions through numerous biochemical mediators, such as growth factors, enzymes, chemokines, coagulation factors, and reactive oxygen species, all of which have the potential to be influenced by numerous host and environmental factors ${ }^{16-19}$. Cardinal among these is transforming growth factor-beta (TGF- $\beta$ ), a potent profibrotic mediator involved in cell recruitment, myofibroblast differentiation, and induction of ECM production ${ }^{18-19}$ (Figure 3).

\section{Disease stratification and personalised medicine}

The early manifestations of IPF are, in the absence of a biopsy, frequently difficult to distinguish from other ILDs. Furthermore, the histological hallmark of IPF, UIP, is found in other disorders and so even when a biopsy is available a diagnosis of IPF can remain in doubt. A further challenge for clinicians is the fact that currently available clinical measures do not allow accurate

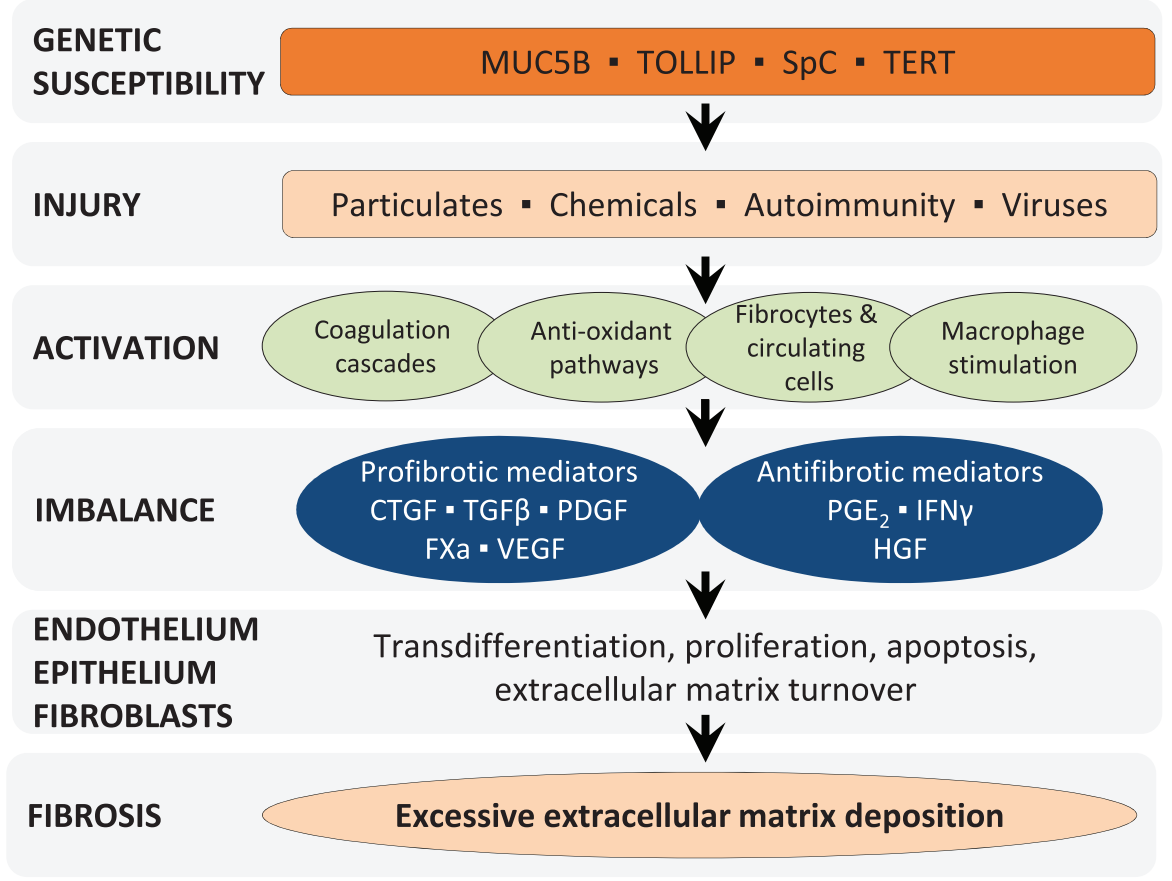

Figure 3. A schematic representing the current model for the pathogenesis of idiopathic pulmonary fibrosis. In genetically susceptible individuals, injury activates multiple inflammatory, cell signalling, and repair pathways. Activation of these cascades causes an imbalance in profibrotic and antifibrotic mediators. In turn, these mediators activate multiple cell types, causing changes in cellular functioning and cell-cell interactions that ultimately result in progressive fibrosis. Abbreviations: CTGF, connective tissue growth factor; FXa, factor Xa; HGF, hepatocyte growth factor; IFN $\gamma$, interferon- $\gamma$; PDGF, platelet-derived growth factor; PGE2, prostaglandin E2; TGF $\beta$, transforming growth factor $\beta$, Th, T-helper; VEGF, vascular endothelial growth factor. 
prediction of subsequent disease behaviour that can range from slowly to rapidly progressive and that, in $5 \%$ of cases, is punctuated by episodes of rapid acute deterioration or acute exacerbation ${ }^{20}$.

These challenges highlight the need for the development and validation of diagnostic markers specific to IPF and prognostic markers of future disease behaviour to guide treatment decisions, including referral for transplant ${ }^{21}$. The recent approval of pirfenidone and nintedanib and the identification of new potential therapeutic targets have created an urgent need for theragnostic markers, i.e. markers able to assess, ideally at an early stage, therapeutic response to a given drug. Such markers could be used to improve patient selection in clinical trials and also to personalise treatment based on an individual's risk of progression and treatment response. This in turn would avoid unnecessarily exposing individuals to side effects and would improve the costeffectiveness of treatment. This approach of disease stratification and personalised medicine is already used in the routine management of cancers and has the potential to improve clinical care in IPF.

\section{Clinical phenotyping}

Several clinical, physiologic, radiographic, and pathologic variables enable a certain degree of mortality prediction in IPF. Older age, male sex, smoking history, low body mass index (BMI), pulmonary hypertension, and concomitant emphysema are clinical predictors of worse survival ${ }^{20}$. Longitudinal changes in forced vital capacity (FVC) and diffusion capacity for carbon monoxide $\left(\mathrm{DL}_{\mathrm{CO}}\right)$ are more predictive of prognosis than baseline values. Thus, a 5-10\% decline in FVC at 6 months is associated with a more than twofold increase in the risk of mortality over the subsequent year ${ }^{22}$. Using relative change in FVC instead of the absolute change enables earlier detection of progression with similar prognostic accuracy ${ }^{23}$. Also reported as independent predictors of mortality are baseline 6-minute walk distance (6MWD) and change in 6MWD at 6 months ${ }^{24}$.

Additionally, several multi-dimensional risk prediction models integrating various clinical, physiological, and radiological variables have been validated in $\operatorname{IPF}^{25-29}$ (Table 1). These composite staging systems are more accurate in predicting baseline and longitudinal mortality risk than individual physiological variables and permit stratification of IPF patients into groups with distinct patterns of survival. Nevertheless, they cannot reliably predict future disease behaviour (as measured by rate of decline in FVC) or response to treatment ${ }^{30}$. Additionally, they provide no insights into underlying pathobiology and thus fail to identify distinct molecular phenotypes of disease. The integration of dynamic parameters measured over time and biological biomarkers able to reflect disease activity is needed to improve the accuracy of disease stratification models and guide personalised management ${ }^{31}$.

Interestingly, the development and greater accessibility of ${ }^{18} \mathrm{~F}$-fluorodeoxyglucose positron emission tomography $\left({ }^{18} \mathrm{~F}-\mathrm{FDG}-\right.$ PET) may provide a novel method for evaluating disease activity in IPF. Areas of established honeycomb fibrosis appear to be highly metabolically active, as shown by increased ${ }^{18} \mathrm{~F}-\mathrm{FDG}$ uptake on PET/CT ${ }^{32}$. More importantly, increased ${ }^{18} \mathrm{~F}$-FDG uptake is also observed in areas of radiologically normal lung parenchyma on HRCT, suggesting that PET/CT may have a higher sensitivity than
HRCT in detecting early disease in IPF and may thus represent a potential useful tool in monitoring disease activity and response to treatment ${ }^{33}$, albeit one which is limited by radiation exposure.

\section{Molecular phenotyping}

High-throughput -omics technologies enable the rapid, accurate, and simultaneous analysis of high numbers of genes, RNA transcripts, proteins, or metabolites. This in turn has facilitated the emergence of systems biology, a multidisciplinary methodology based on integration models aimed at understanding biological systems as a whole, i.e. as a dynamic network of complex interrelated networks extending from the genome to the environment. This contrasts with linear models that have been used in the past to explain the action of individual genes and proteins ${ }^{6}$. Such multiscale modelling should permit mapping of the considerable phenotypic heterogeneity of IPF and may enable the identification of specific molecular phenotypes associated with clinical outcomes that could be used to improve diagnosis accuracy and disease stratification $^{21}$ (Table 2).

Ideal molecular biomarkers should reflect key pathological pathways, be easily and accurately measured, have been validated, and offer added value to currently used approaches ${ }^{34}$. IPF stratification and personalised management based on molecular biomarkers is not yet available in current clinical practice, but recent advances in understanding the complex pathobiology of IPF has identified candidate biomarkers involved in AEC dysfunction, immune dysregulation, ECM remodelling, and fibroproliferation ${ }^{35}$. A prerequisite for the use of biomarkers in clinical practice is validation in large well-phenotyped cohorts with longitudinal follow up of both clinical and molecular parameters. Among several cohort studies are the COMET (Correlating Outcomes With Biochemical Markers to Estimate Time to progression in Idiopathic Pulmonary Fibrosis) study in the United States ${ }^{36-38}$ and the PROFILE (Prospective Observation of Fibrosis in the Lung Clinical Endpoints) study in the United Kingdom ${ }^{39,40}$. The latter is the largest prospective cohort study of incident IPF with over 550 patients recruited, all of whom were naïve for antifibrotic therapy at the time of inclusion.

\section{Genetic phenotyping}

Two large genome-wide association studies (GWAS) have identified several common genetic variants associated with susceptibility to IPF and risk of disease progression. The genes identified are involved in host defence, cell-cell adhesion, and DNA repair ${ }^{41,42}$. A single nucleotide polymorphism (SNP) in the promoter region of the $M U C 5 B$ gene, encoding a mucin involved in airway host defence $^{43}$, is significantly associated with sporadic and familial $\mathrm{IPF}^{44}$ and, paradoxically, with improved survival ${ }^{45}$. This $M U C 5 B$ promoter polymorphism is not associated with lung fibrosis in scleroderma or sarcoidosis and thus appears to be specific to IPF ${ }^{46}$. Similarly, several SNPs conferring susceptibility to IPF have been identified within the TOLLIP locus ${ }^{42}$. The TOLLIP gene encodes for a protein with reduced expression in patients with IPF and that regulates part of the innate immune system mediated by Toll-like receptor and TGF- $\beta$ signalling pathways. Surprisingly, the minor allele rs5743890 in TOLLIP appears to be protective against the development of IPF but when present tends to be associated with increased mortality. 
Studies based on familial IPF have identified rare genetic variants in genes encoding surfactant proteins, including surfactant protein $\mathrm{C}$ (SFTPC) and A2 (SFTPA2), and in several genes linked to telomere function, such as TERT (which encodes for telomerase reverse transcriptase, a component of the telomerase complex responsible for maintaining telomere length ${ }^{47}$ ). Short telomere length as well as evidence of lung parenchymal remodelling and epithelial dysfunction have been identified in asymptomatic first-degree relatives of familial IPF patients and may represent the earliest stages of $\mathrm{IPF}^{48}$. Even in the absence of TERT polymorphisms, short telomeres in peripheral blood mononuclear cells (PBMCs) or in AECs are also frequently found in IPF patients and portend a poorer prognosis ${ }^{47,49}$. This suggests that both genetic variants and environmental factors such as cigarette smoke play a role in telomere shortening.

Table 1. Comparison of mortality risk scoring systems in idiopathic pulmonary fibrosis.

\begin{tabular}{|c|c|c|c|}
\hline & Variables & Predictive value & Advantages (+)/disadvantages (-) \\
\hline $\begin{array}{l}\text { Composite } \\
\text { physiologic index } \\
(\mathrm{CPI})^{25}\end{array}$ & $\begin{array}{l}\mathbf{D L}_{\mathbf{c o}}, \% \text { pred } \\
\text { FVC, \% pred } \\
\text { FEV1, \% pred } \\
\text { Correlation with morphologic } \\
\text { extent: } \\
\text { CPI = } 91.0-\left(0.65 \times \mathbf{D L}_{\mathrm{co}}\right) \\
-(\mathbf{0 . 5 3} \times \mathbf{F V C})+(\mathbf{0 . 3 4} \mathbf{F E V} \mathbf{1})\end{array}$ & $\begin{array}{l}\text { More accurate predictor } \\
\text { of mortality than individual } \\
\text { functional variables }\end{array}$ & $\begin{array}{l}+ \text { : corrects for confounding effects of } \\
\text { emphysema } \\
\text { - : retrospective data; measurement } \\
\text { variability in } \mathrm{DL}_{\mathrm{co}} \text {; not yet been replicated }\end{array}$ \\
\hline du Bois et al. model ${ }^{26}$ & $\begin{array}{l}\text { Age }(0-8 \text { pts }) \\
\text { 24-week history of } \\
\text { respiratory hospitalisation } \\
\text { (0 or } 14 \text { pts }) \\
\text { FVC, \% pred (0-18 pts) } \\
\text { 24-week change in FVC } \\
\text { (0-21 pts) }\end{array}$ & $\begin{array}{l}\text { 1-year mortality risk } \\
\text { Examples of total score: } \\
\text { - } 0-4 \text { pts: > } \% \\
\text { - } 22-29 \text { pts: } 10-20 \% \\
\text { - } 38-40 \text { pts: } 40-50 \% \\
\text { - }>50 \text { pts: }>80 \%\end{array}$ & $\begin{array}{l}+ \text { : easily and reliably evaluable; } \\
\text { longitudinal variables } \\
\text { - : assessed in cohorts with only mild to } \\
\text { moderate physiological impairment at } \\
\text { baseline and with exclusion of severe } \\
\text { emphysema }\end{array}$ \\
\hline $\begin{array}{l}\text { Gender-Age- } \\
\text { Physiology (GAP) } \\
\text { model }^{27}\end{array}$ & $\begin{array}{l}\text { Gender (0-1 pts) } \\
\text { Age (0-2 pts) } \\
\text { FVC, \% pred (0-2 pts) } \\
\text { DL }_{\text {co }} \% \text { pred (0-3 pts) }\end{array}$ & $\begin{array}{l}\text { Cumulative mortality at } \\
\text { 1, 2, and } \mathbf{3} \text { years } \\
\text { Examples of 1-year } \\
\text { mortality risk: } \\
\text { Stage I (0-3 pts): } 6 \% \\
\text { Stage II (4-5 pts): } 16 \% \\
\text { Stage III (6-8 pts): } 39 \%\end{array}$ & $\begin{array}{l}+: \text { : externally validated; GAP calculator as } \\
\text { add-on tool }^{*} \\
\text { - : retrospective data; possible referral bias } \\
\text { (academic centres); tends to overestimate } \\
\text { risk }\end{array}$ \\
\hline $\begin{array}{l}\text { Longitudinal GAP } \\
\text { model }^{28}\end{array}$ & $\begin{array}{l}\text { Gender ( } 0-1 \text { pts) } \\
\text { Age (0-4 pts) } \\
\text { FVC, \% pred (0-15 pts) } \\
\text { 24-week relative change in } \\
\text { FVC (0-12 pts) } \\
\text { DL }_{\text {co } \% \text { pred ( } 0-23 \text { pts) }} \\
\text { Respiratory hospitalisation } \\
\text { (last } 24 \text { weeks) (0 or } 14 \text { pts) }\end{array}$ & $\begin{array}{l}\text { 1- and 2-year mortality } \\
\text { risk } \\
\text { Examples of } 1 \text {-year } \\
\text { mortality risk: } \\
\text { - } 0-10 \text { pts: }<2 \% \\
\text { - } \quad 27-34 \text { pts: } 10-20 \% \\
\text { - } 43-45 \text { pts: } 40-50 \% \\
\text { - } 55-60 \text { pts: } \geq 80 \%\end{array}$ & $\begin{array}{l}\text { + : longitudinal risk assessment; } \\
\text { prospective data } \\
\text { - : no external validation }\end{array}$ \\
\hline CT-GAP model ${ }^{29}$ & $\begin{array}{l}\text { Gender } \\
\text { Age } \\
\text { FVC, \% pred } \\
\text { Quantitative CT fibrosis } \\
\text { score }\end{array}$ & $\begin{array}{l}\text { Cumulative mortality at } \\
\mathbf{1 , 2} \text {, and } \mathbf{3} \text { years } \\
\rightarrow \text { Accuracy comparable } \\
\text { to that of the original GAP } \\
\text { model } \\
\text { Examples of } 1 \text {-year } \\
\text { mortality risk: } \\
\text { Stage I (0-3 pts): } 5 \% \\
\text { Stage II ( } 4-5 \text { pts): } 19 \% \\
\text { Stage III ( } 6-8 \text { pts): } 43 \%\end{array}$ & $\begin{array}{l}+ \text { : alternative model when } \mathrm{DL}_{\mathrm{co}} \\
\text { unmeasurable or not available; externally } \\
\text { validated } \\
\text { - : retrospective data; requires expertise in } \\
\text { quantification of CT disease extent }\end{array}$ \\
\hline
\end{tabular}

Abbreviations: $\mathrm{DL}_{\mathrm{co}}$, diffusing capacity of carbon monoxide; FVC, forced vital capacity; FEV1, forced expiratory volume in 1 second; $C T$, computed tomography; \% pred, \% predicted; pts, points.

${ }^{*}$ GAP calculator for more precise estimation of risk available at www.annals.org 
Table 2. Candidate molecular biomarkers in idiopathic pulmonary fibrosis.

\begin{tabular}{|c|c|c|c|c|}
\hline & Biomarkers & Potential role & Comments & Ref. \\
\hline Genetic & MUC5B promoter SNPs & $\begin{array}{l}\text { Predisposition, } \\
\text { prognosis }\end{array}$ & $\begin{array}{l}\text { rs35705950 (minor allele): increased susceptibility, } \\
\text { improved survival; } \\
\text { rs5743890 (minor allele): reduced susceptibility, } \\
\text { reduced survival }\end{array}$ & $43-45$ \\
\hline Genetic & TOLLIP SNPS & $\begin{array}{l}\text { Predisposition, } \\
\text { prognosis }\end{array}$ & & 42 \\
\hline Genetic & SFTPC, SFTPA2 & Predisposition & & 47 \\
\hline Genetic & $\begin{array}{l}\text { Telomere-related genes } \\
\text { (TERT, TERC, DKC1, RTEL1) }\end{array}$ & Predisposition & $\begin{array}{l}\text { Short telomeres in leucocytes associated with } \\
\text { reduced survival }\end{array}$ & 47 \\
\hline Genetic & Telomere length & $\begin{array}{l}\text { Predisposition, } \\
\text { prognosis }\end{array}$ & & 47,49 \\
\hline Transcriptional & $\begin{array}{l}\text { Lung or peripheral blood } \\
\text { gene expression profiles }\end{array}$ & Diagnosis, prognosis & $\begin{array}{l}\text { Example: LYCAT mRNA expression in leucocytes } \\
\text { correlated with lung function and survival }\end{array}$ & $51-56$ \\
\hline Epigenetic & $\begin{array}{l}\text { Lung or peripheral blood } \\
\text { miRNAs expression profiles }\end{array}$ & $\begin{array}{l}\text { Diagnosis, prognosis, } \\
\text { therapeutic targets }\end{array}$ & $\begin{array}{l}\text { Example: Antifibrotic downregulated miRNAs: miR-29, } \\
\text { Let-7d; } \\
\text { profibrotic upregulated miRNAs: miR-21, miR-154 }\end{array}$ & $64-69$ \\
\hline Blood proteins & $\begin{array}{l}\text { Surfactant proteins (SP-A, } \\
\text { SP-D) }\end{array}$ & Diagnosis, prognosis & Increased levels predictors of worse survival & 71,72 \\
\hline Blood proteins & KL-6/MUC1 & Diagnosis, prognosis & $\begin{array}{l}\text { Increased levels predictors of worse survival and } \\
\text { higher risk of } A E\end{array}$ & 73,82 \\
\hline Blood proteins & cCK18 & Diagnosis & $\begin{array}{l}\text { Higher levels in IPF but no association with disease } \\
\text { severity or outcome }\end{array}$ & 34,35 \\
\hline Blood proteins & CCL18 & Prognosis & $\begin{array}{l}\text { Baseline concentration > } 150 \mathrm{ng} / \mathrm{ml} \text { associated with } \\
\text { higher mortality }\end{array}$ & 74 \\
\hline Blood proteins & CXCL13 & Prognosis & $\begin{array}{l}\text { Elevated levels associated with } \mathrm{PH}, \mathrm{AE} \text {, and worse } \\
\text { survival }\end{array}$ & 75,76 \\
\hline Blood proteins & Anti-HSP70 lgG & Prognosis & $\begin{array}{l}\text { IgG positivity associated with functional decline and } \\
\text { worse survival }\end{array}$ & 34,35 \\
\hline Blood proteins & Periostin & Prognosis & $\begin{array}{l}\text { Higher levels in IPF and correlation with disease } \\
\text { progression }\end{array}$ & 77 \\
\hline Blood proteins & Fibulin-1 & Diagnosis, prognosis & $\begin{array}{l}\text { Elevated levels in IPF and correlation with disease } \\
\text { progression }\end{array}$ & 78 \\
\hline Blood proteins & MMP-1, MMP-7 & Diagnosis, prognosis & $\begin{array}{l}\text { Higher levels associated with disease progression and } \\
\text { worse survival }\end{array}$ & 79,80 \\
\hline Blood proteins & IL-8, ICAM-1 & Prognosis & High concentrations associated with worse survival & 80 \\
\hline Blood proteins & LOXL2 & Prognosis & $\begin{array}{l}\text { Higher levels associated with increased risk for } \\
\text { disease progression }\end{array}$ & 81 \\
\hline Blood proteins & ECM- neoepitopes & Prognosis & $\begin{array}{l}\text { Increased concentrations associated with disease } \\
\text { progression and rate of increase predictor of survival }\end{array}$ & 40 \\
\hline BALF proteins & S100A9 protein & Diagnosis & $\begin{array}{l}\text { Significantly higher levels compared to controls and } \\
\text { other fibrotic ILDs }\end{array}$ & 86 \\
\hline Blood cells & Fibrocytes & Prognosis & $\begin{array}{l}\text { Elevated circulating fibrocytes associated with early } \\
\text { mortality }\end{array}$ & 83 \\
\hline Blood cells & Semaphorin $7 a+$ Tregs & Prognosis & $\begin{array}{l}\text { Increased Sema } 7 a+\text { expression on circulating Tregs } \\
\text { associated with rapidly progressive IPF }\end{array}$ & 84 \\
\hline $\begin{array}{l}\text { Lung } \\
\text { microbiome }\end{array}$ & $\begin{array}{l}\text { Members of Staphylococcus } \\
\text { and Streptococcus genera }\end{array}$ & Prognosis & $\begin{array}{l}\text { Association with disease progression but causal link } \\
\text { not established }\end{array}$ & 38 \\
\hline $\begin{array}{l}\text { Lung } \\
\text { microbiome }\end{array}$ & Total bacterial burden & Prognosis & $\begin{array}{l}\text { Independent predictor of decline in lung function and } \\
\text { mortality but causal link not established }\end{array}$ & 106 \\
\hline
\end{tabular}

Abbreviations: AE, acute exacerbation; BALF, bronchoalveolar lavage fluid; CCK18, caspase-cleaved cytokeratin-18; CCL18, CC-chemokine ligand 18; CXCL13, C-X-C motif chemokine 13; DKC1, dyskeratosis congenital 1 or dyskerin; ECM, extracellular matrix; HSP, heat shock protein; ICAM-1, intercellular adhesion molecule-1; IL-8, interleukin-8; ILDs, interstitial lung diseases; KL-6/MUC1, Krebs von den Lungen-6/Mucin 1; LOXL2, lysyl oxidase-like 2; LYCAT, lysocardiolipin acyltransferase; miRNAs, microRNAs; MMP, matrix metalloproteinases; MUC5B, mucin 5B; PH, pulmonary hypertension; SFTPA2, surfactant protein A2 gene; SFTPC, surfactant protein C gene; RTEL1, regulator of telomere elongation helicase 1; SNPs, single nucleotide polymorphisms; TERC, telomerase RNA component; TERT, telomerase reverse transcriptase; TOLLIP, Toll-interactive protein; Tregs, regulatory T cells. 
The biological role of the various genetic variants in the pathogenesis of IPF has yet to be fully determined. Interestingly, an exploratory post hoc study conducted in a subgroup of patients participating in a multi-centre randomised control trial of $\mathrm{N}$-acetylcysteine treatment for IPF suggests that genetic polymorphisms may play a role in determining $\mathrm{N}$-acetylcysteine treatment response $^{50}$. This remains to be confirmed in a prospective clinical trial.

\section{Transcriptional phenotyping}

Whole RNA microarray analysis of lung tissue from patients with different ILDs has identified disease-specific gene expression signatures that permit UIP to be identified from non-UIP samples $^{51,52}$. Furthermore, the comparison of lung gene expression profiles of patients with stable or rapidly progressive IPF has identified 134 transcripts sufficiently upregulated or downregulated in the progressive IPF group to distinguish stable from progressive disease ${ }^{53}$. Similarly, analysis of the peripheral blood transcriptome in IPF has identified genes differentially expressed between IPF patients and healthy controls and also between those with mild and severe disease ${ }^{54,55}$. For example, mRNA expression of lysocardiolipin acyltransferase (LYCAT), a cardiolipinremodelling enzyme, in PBMCs of IPF patients appeared to be strongly correlated with lung function parameters and survival ${ }^{56}$.

The identification of these diagnostic or prognostic gene expression signatures is a first step towards the development of molecular tests that could be applied to bronchoscopy samples or peripheral blood, thus allowing less invasive approaches to the diagnosis of IPF and earlier identification of individuals at risk of rapid progression.

\section{Epigenetic and microRNA regulation phenotyping}

DNA methylation ${ }^{57,58}$, histone modifications ${ }^{59,60}$, and noncoding microRNAs (miRNAs) ${ }^{61}$ are epigenetic mechanisms identified as contributing to differences in gene expression observed in IPF. These regulatory mechanisms are influenced by various factors including environmental exposures (cigarette smoke and infection), genetic profile, sex, and ageing ${ }^{62}$. A genome-wide DNA methylation analysis of lung tissue identified 2130 significantly differentially methylated regions in IPF samples compared to controls, of which about a third were associated with significant changes in gene expression, including genes identified as IPF-associated common genetic variants ${ }^{63}$. Thus, dysregulated gene expression in the IPF lung appears to result from complex interactions between genetic and epigenetic factors.

miRNAs influence protein expression by binding to mRNA. Aberrant expression of miRNAs has been described in the pathogenesis of many cancers. Lung tissue miRNA profiling identified significantly increased ${ }^{64}$ or decreased ${ }^{65}$ levels of several regulatory miRNAs in IPF patients, thereby distinguishing the normal lung from the IPF lung and rapidly progressive from slowly progressive disease $^{66}$. TGF- $\beta$ seems to play a critical role in the upregulation of profibrotic miRNAs and downregulation of antifibrotic miRNAs ${ }^{67}$.
For example, the direct inhibition of let-7d expression by TGF- $\beta$ in AECs is associated with epithelial to mesenchymal transition and collagen deposition ${ }^{68}$. Similarly, several circulating miRNAs appear to be differentially expressed in the serum of IPF patients ${ }^{67}$. Moreover, the expression levels of miR-21, miR-155, and miR-101-3p in serum seem to be correlated with FVC and HRCT features of $\mathrm{IPF}^{69}$. Interestingly, in mice, intravenous injection of synthetic miR-29 during bleomycin-induced pulmonary fibrosis restored endogenous miR-29 function and was followed by decreasing collagen expression and reversal of pulmonary fibrosis ${ }^{70}$. These changes in miRNA expression in IPF patients suggest that they play an important regulatory role in lung fibrosis and may represent potential diagnostic and prognostic biomarkers as well as therapeutic targets.

\section{Protein and cell biomarkers}

A growing number of studies have sought to identify protein- and cell-based predictors of IPF disease behaviour. Elevated serum levels of several proteins have been associated with worse prognosis in IPF, including surfactant protein A (SP-A) and D (SP-D) ${ }^{71,72}$, mucin 1 (KL-6/MUC1) ${ }^{73}$, CC-chemokine ligand 18 (CCL18) $^{74}$, C-X-C motif chemokine 13 (CXCL13) ${ }^{75,76}$, periostin ${ }^{77}$, fibulin- $1^{78}$, matrix metalloproteinases MMP-1 and MMP- $7^{79,80}$, interleukin-8 (IL-8), intercellular adhesion molecule (ICAM)- $1^{80}$, and lysyl oxidase-like 2 protein (LOXL2) ${ }^{81}$. Elevated baseline serum levels of KL-6/MUC1 also appear to predict the risk of future acute exacerbation $^{82}$. Similarly, some circulating cells have been associated with worse survival. Among cellular markers of rapidly progressive IPF are elevated circulating fibrocytes ${ }^{83}$ and semaphorin $7 \mathrm{a}+$ regulatory $\mathrm{T}$ cells $\left(\right.$ Tregs) ${ }^{84}$.

Serial measurements of serum ECM protein fragments generated by MMP activity in 189 IPF patients recruited in the PROFILE cohort identified increased serum concentrations of these protein fragments in IPF patients compared to controls. More importantly, increasing neoepitope concentrations were associated with disease progression, and the rate of change over 3 months of 3 of these MMP-degraded ECM proteins predicted survival ${ }^{40}$. These results suggest that serial longitudinal measurement of circulating proteins have potential for use as prognostic or theragnostic biomarkers.

Studies based on lung tissue or bronchoalveolar lavage fluid (BALF) analysis have also identified some candidate diagnostic and prognostic biomarkers of IPF, including $\alpha v \beta 6$ integrin $^{85}$, S100A9 protein ${ }^{86}$, and soluble annexin $\mathrm{V}^{87}$.

The value of these protein or cell biomarkers as diagnostic or prognostic factors in IPF needs to be further assessed. Furthermore, integrating validated molecular variables in multivariate risk prediction models could improve their accuracy in predicting outcomes in IPF. In view of this, Richards and colleagues formulated the personal clinical and molecular index (PCMI), integrating sex, FVC $\%$ predicted, $\mathrm{DL}_{\mathrm{CO}} \%$ predicted, and MMP-7 serum concentration, which accurately predicted mortality in their validation cohort ${ }^{80}$. 
Two other prediction models integrating SP-A and SP-D levels or MMP-7, SP-A, and KL-6/MUC1 levels have shown improved predictability of mortality compared with clinical predictors alone $\mathrm{e}^{71,88}$.

\section{Metabolic phenotyping}

Metabolomics is the systematic analysis of the complete set of metabolites (the metabolome) within a biological system under given conditions. This approach offers the potential for a better understanding of dysregulated metabolic pathways underlying numerous diseases, including airway diseases such as asthma, chronic obstructive pulmonary disease (COPD), and cystic fibrosis ${ }^{89}$. Dysregulated metabolic mechanisms have also been highlighted in the pathogenesis of IPF. Increased levels of lactic acid in IPF lung tissue compared with controls appear to play a role in myofibroblast differentiation via a $\mathrm{pH}$-dependent activation of TGF- $\beta^{90}$. Recently, a metabolomic assay by Xie and colleagues demonstrated that augmented aerobic glycolysis, mediated by upregulated glycolytic enzymes, including PFKFB3, represented an early and sustained event during myofibroblast differentiation ${ }^{91}$. More importantly, PFKFB3 inhibition mitigated myofibroblast differentiation and dampened the profibrotic phenotypes of myofibroblasts isolated from IPF lungs. These data suggest that glycolytic reprogramming is important in the pathogenesis of lung fibrosis and therefore represents a potential therapeutic target. More research is needed in the field of metabolomics to clarify the role of these dysregulated pathways of cellular metabolism in the pathogenesis of IPF and to integrate them with available genetic, epigenetic, transcriptomic, and proteomic data.

\section{Environmental and host factors}

Smoking history has long been described as a prevalent risk factor for the development of $\mathrm{IPF}^{92}$, including familial $\mathrm{IPF}^{93}$, and is associated with a worse survival ${ }^{94}$. Some other environmental and occupational exposures, including wood, mineral, and metal dusts, agriculture, and livestock, have also been associated with IPF, although a formal causal link has not been established ${ }^{95}$. Furthermore, air pollution may also play a role in the pathogenesis of IPF. A recent study reported a significantly higher risk of acute exacerbation of IPF with increased ozone and nitrogen dioxide exposure over the preceding 6 weeks ${ }^{96}$.

Gastroesophageal reflux (GER) is highly prevalent in IPF, though often asymptomatic, and confers an increased risk of microaspiration ${ }^{97}$. Anti-acid treatment in IPF has been associated in retrospective data with decreased radiologic fibrosis, longer survival, and smaller decrease of FVC at 30 weeks ${ }^{98,99}$. Despite growing evidence suggesting that GER and silent microaspiration might play a role in the pathogenesis of IPF, there is, to date, no confirmation that this association is causative. Consequently, the recently updated international guidelines on IPF treatment maintained a conditional recommendation for the use of anti-acid therapy ${ }^{100}$. A prospective randomised controlled trial is needed to further assess the role of GER and microaspiration in IPF and confirm the effectiveness of anti-reflux therapy.
Infectious processes may play a role in the initiation, progression, or exacerbation of IPF. Viral infections, particularly human herpes viruses (HHVs), including herpes simplex virus type 1 (HSV-1), Epstein-Barr virus (EBV), cytomegalovirus (CMV), HHV-7, and HHV-8, have been associated with IPF in several studies ${ }^{101}$. Whether this association is causative has not yet been proven. HHVs have the potential to induce endoplasmic reticulum stress and apoptosis ${ }^{102}$; it is therefore hypothesised that viral infection may act as a cofactor in the development of IPF through the reactivation of latent HHVs within the alveolar epithelium following exposure to a first injury ${ }^{103}$. Furthermore, a recent study found increased copy numbers of EBV and CMV DNA in BALF of IPF patients and, to a lesser extent, in first-degree asymptomatic relatives of familial IPF patients ${ }^{48}$. Thus, enhanced HHV replication may trigger epithelial cell stress and participate in disease initiation. A small clinical trial of ganciclovir in individuals with severe IPF with positive EBV-IgG serology showed a modest improvement in surrogate markers of disease progression ${ }^{104}$. It has recently been reported that influenza infection may also play a role in lung fibrosis by promoting collagen deposition via $\alpha v \beta 6$ integrin-mediated TGF- $\beta$ activation in epithelial cells ${ }^{105}$.

Recent data also suggest a putative role for bacteria and lung microbiome in IPF. An analysis of the COMET study showed an association between progression of IPF and the presence of specific members within the Staphylococcus and Streptococcus genera in $\mathrm{BALF}^{38}$. Similarly, Molyneaux and colleagues found an increased bacterial load, consisting particularly of Haemophilus, Streptococcus, Neisseria, and Veillonella spp., in BALF of IPF patients compared to healthy smokers, nonsmokers, and patients with moderate $\mathrm{COPD}^{106}$. More importantly, the total bacterial burden was an independent predictor of decline in lung function and mortality. Whether these differences in lung microbiome are a cause or consequence of IPF is unknown. A clinical trial of 12 months of co-trimoxazole in addition to standard treatment in 181 patients with fibrotic idiopathic interstitial pneumonia (about $90 \%$ of whom had IPF) showed a reduction in mortality but did not slow functional decline ${ }^{107}$. The exact role of viruses and bacteria in the pathogenesis of IPF has yet to be determined and the potential for antiviral or antibiotic treatments requires further evaluation.

\section{Conclusion}

Currently available therapies for IPF are of limited efficacy, and the prognosis associated with the condition remains poor. Recent advances in our understanding of the complex interrelated mechanisms underlying fibrosis in the lung are encouraging and pave the way towards an integrated approach to diagnosis, stratification, and treatment. It is becoming increasingly clear that genetic polymorphisms, whole blood transcriptomic profile, and lavage microbiome all predict groups of patients with differing disease behaviour and outcomes and potentially variable responses to treatment. Furthermore, prospective longitudinal cohort studies have started to identify blood biomarkers that have the potential 
to be used as early measures of treatment response. Considerable further research is required to deliver personalised medicine for IPF into the clinic, but at least now there is light at the end of what has been a very long tunnel.

\section{Competing interests}

Cécile Daccord does not have competing interests to report. Toby Maher has no declarations directly related to this manuscript. He has, however, received industry-academic research funding from GlaxoSmithKline R\&D, UCB, and Novartis and has received consultancy or speakers fees from Apellis, Bayer, Biogen Idec,
Boehringer Ingelheim, Dosa, GlaxoSmithKline R\&D, Galapagos, Novartis, ProMetic, Roche, Sanofi-Aventis, and UCB.

\section{Grant information}

Cécile Daccord is supported by Ligue Pulmonaire Vaudoise, Service de pneumologie CHUV, and Fonds de perfectionnement CHUV. Toby M Maher is supported by an NIHR Clinician Scientist Fellowship (NIHR Ref: CS-2013-13-017) and receives additional infrastructure support from the Royal Brompton NIHR funded biomedical research unit.

The funders had no role in study design, data collection and analysis, decision to publish, or preparation of the manuscript.
1. Hutchinson J, Fogarty A, Hubbard R, et al:: Global incidence and mortality of idiopathic pulmonary fibrosis: a systematic review. Eur Respir J. 2015; 46(3) 795-806.

PubMed Abstract | Publisher Full Text

2. Vancheri C, Failla M, Crimi N, et al.: Idiopathic pulmonary fibrosis: a disease with similarities and links to cancer biology. Eur Respir J. 2010; 35(3): 496-504. PubMed Abstract | Publisher Full Text

3. F King TE Jr, Bradford WZ, Castro-Bernardini S, et al.: A phase $\mathbf{3}$ trial of pirfenidone in patients with idiopathic pulmonary fibrosis. N Engl J Med. 2014 370(22): 2083-92.

PubMed Abstract | Publisher Full Text | F1000 Recommendation

4. $\quad F$ Richeldi L, du Bois RM, Raghu G, et al.: Efficacy and safety of nintedanib in idiopathic pulmonary fibrosis. N Engl J Med. 2014; 370(22): 2071-82. PubMed Abstract | Publisher Full Text | F1000 Recommendation

5. Gonzalez de Castro D, Clarke PA, Al-Lazikani B, et al.: Personalized cancer medicine: molecular diagnostics, predictive biomarkers, and drug resistance. Clin Pharmacol Ther. 2013; 93(3): 252-9.

PubMed Abstract | Publisher Full Text | Free Full Text

6. Pathak RR, Davé V: Integrating omics technologies to study pulmonary physiology and pathology at the systems level. Cell Physiol Biochem. 2014; 33(5): 1239-60.

PubMed Abstract | Publisher Full Text | Free Full Text

7. Woodcock HV, Maher TM: The treatment of idiopathic pulmonary fibrosis. F1000Prime Rep. 2014; 6: 16.

PubMled Abstract | Publisher Full Text | Free Full Text

8. Raghu G, Collard HR, Egan JJ, et al.: An official ATS/ERS/JRS/ALAT statement: idiopathic pulmonary fibrosis: evidence-based guidelines for diagnosis and management. Am J Respir Crit Care Med. 2011; 183(6): 788-824. PubMed Abstract | Publisher Full Text

9. Hutchinson JP, Fogarty AW, McKeever TM, et al:: In-Hospital Mortality after Surgical Lung Biopsy for Interstitial Lung Disease in the United States. 2000 to 2011. Am J Respir Crit Care Med. 2016; 193(10): 1161-7. PubMed Abstract | Publisher Full Text

10. F Ryerson CJ, Urbania TH, Richeldi L, et al.: Prevalence and prognosis of unclassifiable interstitial lung disease. Eur Respir J. 2013; 42(3): 750-7. PubMed Abstract | Publisher Full Text | F1000 Recommendation

11. F Tomassetti S, Wells AU, Costabel U, et al:: Bronchoscopic Lung Cryobiopsy Increases Diagnostic Confidence in the Multidisciplinary Diagnosis of Idiopathic Pulmonary Fibrosis. Am J Respir Crit Care Med. 2016; 193(7): 745-52. PubMed Abstract | Publisher Full Text | F1000 Recommendation

12. Maher TM, Wells AU, Laurent GJ: Idiopathic pulmonary fibrosis: multiple causes and multiple mechanisms? Eur Respir J. 2007; 30(5): 835-9. PubMed Abstract | Publisher Full Text

13. Wuyts WA, Antoniou KM, Borensztajn K, et al.: Combination therapy: the future of management for idiopathic pulmonary fibrosis? Lancet Respir Med. 2014; 2(11): 933-42.

PubMed Abstract | Publisher Full Text
14. King TE Jr, Pardo A, Selman M: Idiopathic pulmonary fibrosis. Lancet. 2011; 378(9807): 1949-61.

PubMed Abstract | Publisher Full Text

15. Ahluwalia N, Shea BS, Tager AM: New therapeutic targets in idiopathic pulmonary fibrosis. Aiming to rein in runaway wound-healing responses. $A m \mathrm{~J}$ Respir Crit Care Med. 2014; 190(8): 867-78.

PubMed Abstract | Publisher Full Text | Free Full Text

16. $\mathrm{F}$ Bagnato $\mathrm{G}$, Harari $\mathrm{S}$ : Cellular interactions in the pathogenesis of interstitial lung diseases. Eur Respir Rev. 2015; 24(135): 102-14.

PubMed Abstract | Publisher Full Text | F1000 Recommendation

17. Wolters PJ, Collard HR, Jones KD: Pathogenesis of idiopathic pulmonary fibrosis. Annu Rev Pathol. 2014; 9: 157-79.

PubMed Abstract | Publisher Full Text | Free Full Text

18. Selman M, Pardo A: Revealing the pathogenic and aging-related mechanisms of the enigmatic idiopathic pulmonary fibrosis. an integral model. Am J Respir Crit Care Med. 2014; 189(10): 1161-72. PubMed Abstract | Publisher Full Text

19. Wuyts WA, Agostini C, Antoniou KM, et al.: The pathogenesis of pulmonary fibrosis: a moving target. Eur Respir J. 2013; 41(5): 1207-18. PubMed Abstract | Publisher Full Text

20. Ley B, Collard HR, King TE Jr: Clinical course and prediction of survival in idiopathic pulmonary fibrosis. Am J Respir Crit Care Med. 2011; 183(4): 431-40. PubMed Abstract | Publisher Full Text

21. Maher TM: Beyond the diagnosis of idiopathic pulmonary fibrosis; the growing role of systems biology and stratified medicine. Curr Opin Pulm Med. 2013; 19(5): 460-5.

PubMed Abstract | Publisher Full Text

22. du Bois RM, Weycker D, Albera C, et al.: Forced vital capacity in patients with idiopathic pulmonary fibrosis: test properties and minimal clinically important difference. Am J Respir Crit Care Med. 2011; 184(12): 1382-9. PubMed Abstract | Publisher Full Text

23. Richeldi L, Ryerson CJ, Lee JS, et al.: Relative versus absolute change in forced vital capacity in idiopathic pulmonary fibrosis. Thorax. 2012; 67(5): 407-11. PubMed Abstract | Publisher Full Text

24. F du Bois RM, Albera C, Bradford WZ, et al:: 6-Minute walk distance is an independent predictor of mortality in patients with idiopathic pulmonary fibrosis. Eur Respir J. 2014; 43(5): 1421-9. PubMed Abstract | Publisher Full Text | F1000 Recommendation

25. Wells AU, Desai SR, Rubens MB, et al:: Idiopathic pulmonary fibrosis: a composite physiologic index derived from disease extent observed by computed tomography. Am J Respir Crit Care Med. 2003; 167(7): 962-9. PubMed Abstract | Publisher Full Text

26. F du Bois RM, Weycker D, Albera C, et al:: Ascertainment of individual risk of mortality for patients with idiopathic pulmonary fibrosis. Am J Respir Crit Care Med. 2011; 184(4): 459-66.

PubMed Abstract | Publisher Full Text | F1000 Recommendation 
27. Ley B, Ryerson CJ, Vittinghoff E, et al.: A multidimensional index and staging system for idiopathic pulmonary fibrosis. Ann Intern Med. 2012; 156(10): 684-91. PubMed Abstract | Publisher Full Text

28. F Ley B, Bradford WZ, Weycker D, et al:: Unified baseline and longitudinal mortality prediction in idiopathic pulmonary fibrosis. Eur Respir J. 2015; 45(5) 1374-81.

PubMed Abstract | Publisher Full Text | F1000 Recommendation

29. F Ley B, Elicker BM, Hartman TE, et al.: Idiopathic pulmonary fibrosis: $\mathrm{CT}$ and risk of death. Radiology. 2014; 273(2): 570-9.

PubMed Abstract | Publisher Full Text | F1000 Recommendation

30. Salisbury ML, Xia M, Zhou Y, et al.: Idiopathic Pulmonary Fibrosis: Gender-AgePhysiology Index Stage for Predicting Future Lung Function Decline. Chest. 2016; 149(2): 491-8.

PubMed Abstract | Publisher Full Text

31. F Kolb M, Collard HR: Staging of idiopathic pulmonary fibrosis: past, present and future. Eur Respir Rev. 2014; 23(132): 220-4.

PubMed Abstract | Publisher Full Text | F1000 Recommendation

32. Win T, Lambrou T, Hutton BF, et al:: ${ }^{18} \mathrm{~F}$-Fluorodeoxyglucose positron emission tomography pulmonary imaging in idiopathic pulmonary fibrosis is reproducible: implications for future clinical trials. Eur J Nucl Med Mol Imaging 2012; 39(3): 521-8.

PubMed Abstract | Publisher Full Text

33. Win T, Thomas BA, Lambrou T, et al:: Areas of normal pulmonary parenchyma on HRCT exhibit increased FDG PET signal in IPF patients. Eur J NuCl Med Mol Imaging. 2014; 41(2): 337-42.

PubMed Abstract | Publisher Full Text | Free Full Text

34. F Ley B, Brown KK, Collard HR: Molecular biomarkers in idiopathic pulmonary fibrosis. Am J Physiol Lung Cell Mol Physiol. 2014; 307(9): L681-91. PubMed Abstract | Publisher Full Text | Free Full Text | F1000 Recommendation

35. Spagnolo $P$, Tzouvelekis A, Maher TM: Personalized medicine in idiopathic pulmonary fibrosis: facts and promises. Curr Opin Pulm Med. 2015; 21(5): 470-8.

PubMed Abstract | Publisher Full Text

36. Huie TJ, Moss M, Frankel SK: What can biomarkers tell us about the pathogenesis of acute exacerbations of idiopathic pulmonary fibrosis? Am J Physiol Lung Cell Mol Physiol. 2010; 299(1): L1-2.

PubMed Abstract | Publisher Full Text

37. Naik PK, Bozyk PD, Bentley JK, et al.: Periostin promotes fibrosis and predicts progression in patients with idiopathic pulmonary fibrosis. Am J Physiol Lung Cell Mol Physiol. 2012; 303(12): L1046-56.

PubMed Abstract | Publisher Full Text | Free Full Text

38. F Han MK, Zhou Y, Murray S, et al:: Lung microbiome and disease progression in idiopathic pulmonary fibrosis: an analysis of the COMET study. Lancet Respir Med. 2014; 2(7): 548-56.

PubMed Abstract | Publisher Full Text | Free Full Text | F1000 Recommendation

39. Maher TM: PROFILEing idiopathic pulmonary fibrosis: rethinking biomarker discovery. Eur Respir Rev. 2013; 22(128): 148-52.

PubMed Abstract | Publisher Full Text

40. Jenkins RG, Simpson JK, Saini G, et al:: Longitudinal change in collagen degradation biomarkers in idiopathic pulmonary fibrosis: an analysis from the prospective, multicentre PROFILE study. Lancet Respir Med. 2015; 3(6): 462-72. PubMed Abstract | Publisher Full Text

41. F Fingerlin TE, Murphy E, Zhang W, et al:: Genome-wide association study identifies multiple susceptibility loci for pulmonary fibrosis. Nat Genet. 2013; 45(6): 613-20.

PubMed Abstract | Publisher Full Text | Free Full Text | F1000 Recommendation

42. $F$ Noth I, Zhang Y, Ma SF, et al:: Genetic variants associated with idiopathic pulmonary fibrosis susceptibility and mortality: a genome-wide association study. Lancet Respir Med. 2013; 1(4): 309-17.

PubMed Abstract | Publisher Full Text | Free Full Text | F1000 Recommendation

43. F Roy MG, Livraghi-Butrico A, Fletcher AA, et al: Muc5b is required for airway defence. Nature. 2014; 505(4783): 412-6.

PubMed Abstract | Publisher Full Text | Free Full Text | F1000 Recommendation

44. F Seibold MA, Wise AL, Speer MC, et al.: A common MUC5B promoter polymorphism and pulmonary fibrosis. N Engl J Med. 2011; 364(16): 1503-12. PubMed Abstract | Publisher Full Text | Free Full Text | F1000 Recommendation

45. F Peljto AL, Zhang Y, Fingerlin TE, et al.: Association between the MUC5B promoter polymorphism and survival in patients with idiopathic pulmonary fibrosis. JAMA. 2013; 309(21): 2232-9.

PubMed Abstract | Publisher Full Text | Free Full Text | F1000 Recommendation

46. Stock $\mathrm{CJ}$, Sato $\mathrm{H}$, Fonseca $\mathrm{C}$, et al.: Mucin $\mathbf{5 B}$ promoter polymorphism is associated with idiopathic pulmonary fibrosis but not with development of lung fibrosis in systemic sclerosis or sarcoidosis. Thorax. 2013; 68(5): 436-41. PubMed Abstract | Publisher Full Text

47. F Kropski JA, Blackwell TS, Loyd JE: The genetic basis of idiopathic pulmonary fibrosis. Eur Respir J. 2015; 45(6): 1717-27.

PubMed Abstract | Publisher Full Text | Free Full Text | F1000 Recommendation

48. F Kropski JA, Pritchett JM, Zoz DF, et al:: Extensive phenotyping of individuals at risk for familial interstitial pneumonia reveals clues to the pathogenesis of interstitial lung disease. Am J Respir Crit Care Med. 2015; 191(4): 417-26. PubMed Abstract | Publisher Full Text | Free Full Text | F1000 Recommendation

49. F Stuart BD, Lee JS, Kozlitina J, et al.: Effect of telomere length on survival in patients with idiopathic pulmonary fibrosis: an observational cohort study with independent validation. Lancet Respir Med. 2014; 2(7): 557-65.

PubMed Abstract | Publisher Full Text | Free Full Text | F1000 Recommendation

50. F Oldham JM, Ma SF, Martinez FJ, et al.: TOLLIP, MUC5B, and the Response to N-Acetylcysteine among Individuals with Idiopathic Pulmonary Fibrosis. Am J Respir Crit Care Med. 2015; 192(12): 1475-82.

PubMed Abstract | Publisher Full Text | Free Full Text | F1000 Recommendation

51. F Selman M, Pardo A, Barrera L, et al.: Gene expression profiles distinguish idiopathic pulmonary fibrosis from hypersensitivity pneumonitis. Am J Respir Crit Care Med. 2006; 173(2): 188-98.

PubMed Abstract | Publisher Full Text | Free Full Text | F1000 Recommendation

52. F Kim SY, Diggans J, Pankratz D, et al.: Classification of usual interstitial pneumonia in patients with interstitial lung disease: assessment of a machine learning approach using high-dimensional transcriptional data. Lancet Respir Med. 2015; 3(6): 473-82.

PublMed Abstract | Publisher Full Text | F1000 Recommendation

53. F Boon K, Bailey NW, Yang J, et al.: Molecular phenotypes distinguish patients with relatively stable from progressive idiopathic pulmonary fibrosis (IPF). PLoS One. 2009; 4(4): e5134.

PubMed Abstract | Publisher Full Text | Free Full Text | F1000 Recommendation

54. F Yang IV, Luna LG, Cotter J, et al:: The peripheral blood transcriptome identifies the presence and extent of disease in idiopathic pulmonary fibrosis. PLoS One. 2012; 7(6): e37708.

PubMed Abstract | Publisher Full Text | Free Full Text | F1000 Recommendation

55. F Meltzer EB, Barry WT, Yang IV, et al.: Familial and sporadic idiopathic pulmonary fibrosis: making the diagnosis from peripheral blood. BMC Genomics. 2014; 15(1): 902

PubMed Abstract | Publisher Full Text | Free Full Text | F1000 Recommendation

56. F Huang LS, Mathew B, Li H, et al.: The mitochondrial cardiolipin remodeling enzyme lysocardiolipin acyltransferase is a novel target in pulmonary fibrosis. Am J Respir Crit Care Med. 2014; 189(11): 1402-15.

PubMed Abstract | Publisher Full Text | Free Full Text | F1000 Recommendation

57. F Sanders YY, Ambalavanan N, Halloran B, et al:: Altered DNA methylation profile in idiopathic pulmonary fibrosis. Am J Respir Crit Care Med. 2012; 186(6): 525-35.

PubMed Abstract | Publisher Full Text | Free Full Text | F1000 Recommendation

58. F Huang SK, Scruggs AM, McEachin RC, et al:: Lung fibroblasts from patients with idiopathic pulmonary fibrosis exhibit genome-wide differences in DNA methylation compared to fibroblasts from nonfibrotic lung. PLOS One. 2014; 9(9): e107055.

PubMed Abstract | Publisher Full Text | Free Full Text | F1000 Recommendation

59. F Coward WR, Watts K, Feghali-Bostwick CA, et al.: Defective histone acetylation is responsible for the diminished expression of cyclooxygenase 2 in idiopathic pulmonary fibrosis. Mol Cell Biol. 2009; 29(15): 4325-39. PubMed Abstract | Publisher Full Text | Free Full Text | F1000 Recommendation

60. Coward WR, Watts K, Feghali-Bostwick CA, et al:: Repression of IP-10 by interactions between histone deacetylation and hypermethylation in idiopathic pulmonary fibrosis. Mol Cell Biol. 2010; 30(12): 2874-86.

PubMed Abstract | Publisher Full Text | Free Full Text

61. Dakhlallah D, Batte $\mathrm{K}$, Wang $\mathrm{Y}$, et al.: Epigenetic regulation of $\mathbf{m i R - 1 7 \sim 9 2}$ contributes to the pathogenesis of pulmonary fibrosis. Am J Respir Crit Care Med. 2013; 187(4): 397-405.

PubMed Abstract | Publisher Full Text | Free Full Text

62. F Yang IV, Schwartz DA: Epigenetics of idiopathic pulmonary fibrosis. Transl Res. 2015; 165(1): 48-60.

PubMed Abstract | Publisher Full Text | Free Full Text | F1000 Recommendation

63. F Yang IV, Pedersen BS, Rabinovich E, et al:: Relationship of DNA methylation and gene expression in idiopathic pulmonary fibrosis. Am J Respir Crit Care Med. 2014; 190(11): 1263-72.

PubMed Abstract | Publisher Full Text | Free Full Text | F1000 Recommendation

64. Milosevic J, Pandit K, Magister M, et al.: Profibrotic role of miR-154 in pulmonary fibrosis. Am J Respir Cell Mol Biol. 2012; 47(6): 879-87.

PubMed Abstract | Publisher Full Text | Free Full Text

65. Pandit KV, Corcoran D, Yousef H, et al:: Inhibition and role of let-7d in idiopathic pulmonary fibrosis. Am J Respir Crit Care Med. 2010; 182(2): 220-9. PubMed Abstract | Publisher Full Text | Free Full Text

66. F Oak SR, Murray L, Herath A, et al:: A micro RNA processing defect in rapidly progressing idiopathic pulmonary fibrosis. PLOS One. 2011; 6(6): e21253. PubMed Abstract | Publisher Full Text | Free Full Text | F1000 Recommendation

67. F Cui H, Xie N, Thannickal VJ, et al.: The code of non-coding RNAs in lung fibrosis. Cell Mol Life Sci. 2015; 72(18): 3507-19. PubMed Abstract | Publisher Full Text | Free Full Text | F1000 Recommendation

68. F Yang G, Yang L, Wang W, et al.: Discovery and validation of extracellular/ circulating microRNAs during idiopathic pulmonary fibrosis disease progression. Gene. 2015; 562(1): 138-44. progression. Gene. $2015 ; 562(1): 138-44$.
PubMed Abstract | Publisher Full Text | F1000 Recommendation 
69. $\mathrm{F}$ LiP $\mathrm{LiJ}$ Chen $\mathrm{T}$, et al: Expression analysis of serum microRNAs in idiopathic pulmonary fibrosis. Int J Mol Med. 2014; 33(6): 1554-62. PubMed Abstract | Publisher Full Text | F1000 Recommendation

70. F Montgomery RL, Yu G, Latimer PA, et al:: MicroRNA mimicry blocks pulmonary fibrosis. EMBO Mol Med. 2014; 6(10): 1347-56. PubMed Abstract | Publisher Full Text | Free Full Text | F1000 Recommendation

71. Kinder BW, Brown KK, McCormack FX, et al.: Serum surfactant protein-A is a strong predictor of early mortality in idiopathic pulmonary fibrosis. Chest. 2009; 135(6): 1557-63.

PubMed Abstract | Publisher Full Text | Free Full Text

72. Barlo NP, van Moorsel $\mathrm{CH}$, Ruven $\mathrm{HJ}$, et al.: Surfactant protein-D predicts survival in patients with idiopathic pulmonary fibrosis. Sarcoidosis Vasc Diffuse Lung Dis. 2009; 26(2): 155-61. PubMed Abstract

73. Yokoyama A, Kondo K, Nakajima M, et al.: Prognostic value of circulating KL-6 in idiopathic pulmonary fibrosis. Respirology. 2006; 11(2): 164-8. PubMed Abstract | Publisher Full Text

74. F Prasse A, Probst C, Bargagli E, et al:: Serum CC-chemokine ligand 18 concentration predicts outcome in idiopathic pulmonary fibrosis. Am J Respir Crit Care Med. 2009; 179(8): 717-23. PubMed Abstract | Publisher Full Text | F1000 Recommendation

75. F Vuga LJ, Tedrow JR, Pandit KV, et al:: C-X-C motif chemokine 13 (CXCL13) is a prognostic biomarker of idiopathic pulmonary fibrosis. Am J Respir Crit Care Med. 2014; 189(8): 966-74.

PubMed Abstract | Publisher Full Text | Free Full Text | F1000 Recommendation

76. F DePianto DJ, Chandriani S, Abbas AR, et al.: Heterogeneous gene expression signatures correspond to distinct lung pathologies and biomarkers of disease severity in idiopathic pulmonary fibrosis. Thorax. 2015; 70(1): 48-56. PubMed Abstract | Publisher Full Text | Free Full Text | F1000 Recommendation

77. Naik PK, Bozyk PD, Bentley JK, et al.: Periostin promotes fibrosis and predicts progression in patients with idiopathic pulmonary fibrosis. Am J Physiol Lung Cell Mol Physiol. 2012; 303(12): L1046-56.

PubMed Abstract | Publisher Full Text | Free Full Text

78. F Jaffar J, Unger S, Corte TJ, et al:: Fibulin-1 predicts disease progression in patients with idiopathic pulmonary fibrosis. Chest. 2014; 146(4): 1055-63. PubMed Abstract | Publisher Full Text | Free Full Text | F1000 Recommendation

79. F Rosas IO, Richards TJ, Konishi K, et al.: MMP1 and MMP7 as potential peripheral blood biomarkers in idiopathic pulmonary fibrosis. PLOS Med. 2008; 5(4): e93.

PubMed Abstract | Publisher Full Text | Free Full Text | F1000 Recommendation

80. F Richards TJ, Kaminski N, Baribaud F, et al.: Peripheral blood proteins predict mortality in idiopathic pulmonary fibrosis. Am J Respir Crit Care Med. 2012; 185(1): 67-76.

PubMed Abstract | Publisher Full Text | Free Full Text | F1000 Recommendation

81. F Chien JW, Richards TJ, Gibson KF, et al:: Serum lysyl oxidase-like 2 levels and idiopathic pulmonary fibrosis disease progression. Eur Respir J. 2014; 43(5): $1430-8$.

PubMed Abstract | Publisher Full Text | F1000 Recommendation

82. F Ohshimo S, Ishikawa N, Horimasu Y, et al.: Baseline KL-6 predicts increased risk for acute exacerbation of idiopathic pulmonary fibrosis. Respir Med. 2014; 108(7): 1031-9.

PubMed Abstract | Publisher Full Text | F1000 Recommendation

83. F Moeller A, Gilpin SE, Ask K, et al: Circulating fibrocytes are an indicator of poor prognosis in idiopathic pulmonary fibrosis. Am J Respir Crit Care Med. 2009; 179(7): 588-94.

PubMed Abstract | Publisher Full Text | F1000 Recommendation

84. F Reilkoff RA, Peng H, Murray LA, et al:: Semaphorin $7 a^{+}$regulatory $\mathrm{T}$ cells are associated with progressive idiopathic pulmonary fibrosis and are implicated in transforming growth factor- $\beta 1$-induced pulmonary fibrosis. Am J Respir Crit Care Med. 2013; 187(2): 180-8.

PubMed Abstract | Publisher Full Text | Free Full Text | F1000 Recommendation

85. F Saini G, Porte J, Weinreb PH, et al.: $\alpha v \beta 6$ integrin may be a potential prognostic biomarker in interstitial lung disease. Eur Respir J. 2015; 46(2): 486-94.

PubMed Abstract | Publisher Full Text | F1000 Recommendation

86. Hara A, Sakamoto N, Ishimatsu $Y$, et al:: S100A9 in BALF is a candidate biomarker of idiopathic pulmonary fibrosis. Respir Med. 2012; 106(4): 571-80. PubMed Abstract | Publisher Full Text

87. F Buckley S, Shi W, Xu W, et al:: Increased alveolar soluble annexin V promotes lung inflammation and fibrosis. Eur Respir J. 2015; 46(5): 1417-29. PubMed Abstract | Publisher Full Text | Free Full Text | F1000 Recommendation

88. Song JW, Do KH, Jang SJ, et al.: Blood biomarkers MMP-7 and SP-A: predictors of outcome in idiopathic pulmonary fibrosis. Chest. 2013; 143(5): 1422-9. PubMed Abstract | Publisher Full Text
89. F Nobakht M Gh BF, Aliannejad R, Rezaei-Tavirani M, et al: The metabolomics of airway diseases, including COPD, asthma and cystic fibrosis. Biomarkers. 2015; 20(1): 5-16.

PubMed Abstract | Publisher Full Text | F1000 Recommendation

90. $\quad F$ Kottmann RM, Kulkarni AA, Smolnycki KA, et al:: Lactic acid is elevated in idiopathic pulmonary fibrosis and induces myofibroblast differentiation via pH-dependent activation of transforming growth factor- $\beta$. Am J Respir Crit Care Med. 2012; 186(8): 740-51.

PubMed Abstract | Publisher Full Text | Free Full Text | F1000 Recommendation

91. F Xie N, Tan Z, Banerjee S, et al.: Glycolytic Reprogramming in Myofibroblast Differentiation and Lung Fibrosis. Am J Respir Crit Care Med. 2015; 192(12): 1462-74.

PubMed Abstract | Publisher Full Text | Free Full Text | F1000 Recommendation

92. Baumgartner KB, Samet JM, Stidley CA, et al.: Cigarette smoking: a risk factor for idiopathic pulmonary fibrosis. Am J Respir Crit Care Med. 1997; 155(1): 242-8. PubMed Abstract | Publisher Full Text

93. Steele MP, Speer MC, Loyd JE, et al.: Clinical and pathologic features of familial interstitial pneumonia. Am J Respir Crit Care Med. 2005; 172(9): 1146-52. PubMed Abstract | Publisher Full Text | Free Full Text

94. Antoniou KM, Hansell DM, Rubens MB, et al:: Idiopathic pulmonary fibrosis: outcome in relation to smoking status. Am J Respir Crit Care Med. 2008; 177(2): $190-4$.

PubMed Abstract | Publisher Full Text

95. Taskar VS, Coultas DB: Is idiopathic pulmonary fibrosis an environmental disease? Proc Am Thorac Soc. 2006; 3(4): 293-8. PubMed Abstract | Publisher Full Text

96. F Johannson KA, Vittinghoff E, Lee K, et al:: Acute exacerbation of idiopathic pulmonary fibrosis associated with air pollution exposure. Eur Respir J. 2014 43(4): 1124-31.

PubMed Abstract | Publisher Full Text | F1000 Recommendation

97. Savarino E, Carbone R, Marabotto E, et al.: Gastro-oesophageal reflux and gastric aspiration in idiopathic pulmonary fibrosis patients. Eur Respir J. 2013; 42(5): 1322-31.

PubMed Abstract | Publisher Full Text

98. F Lee JS, Ryu JH, Elicker BM, et al.: Gastroesophageal reflux therapy is associated with longer survival in patients with idiopathic pulmonary fibrosis. Am J Respir Crit Care Med. 2011; 184(12): 1390-4.

PubMed Abstract | Publisher Full Text | Free Full Text | F1000 Recommendation

99. Lee JS, Collard HR, Anstrom KJ, et al.: Anti-acid treatment and disease progression in idiopathic pulmonary fibrosis: an analysis of data from three randomised controlled trials. Lancet Respir Med. 2013; 1(5): 369-76. PubMed Abstract | Publisher Full Text | Free Full Text

100. F Raghu G, Rochwerg B, Zhang Y, et al:: An Official ATS/ERS/JRS/ALAT Clinical Practice Guideline: Treatment of Idiopathic Pulmonary Fibrosis. An Update of the 2011 Clinical Practice Guideline. Am J Respir Crit Care Med. 2015; 192(2): e3-19.

PubMed Abstract | Publisher Full Text | F1000 Recommendation

101. Molyneaux PL, Maher TM: The role of infection in the pathogenesis of idiopathic pulmonary fibrosis. Eur Respir Rev. 2013; 22(129): 376-81. PubMed Abstract | Publisher Full Text

102. Lawson WE, Crossno PF, Polosukhin VV, et al.: Endoplasmic reticulum stress in alveolar epithelial cells is prominent in IPF: association with altered surfactant protein processing and herpesvirus infection. Am J Physiol Lung Cell Mol Physiol. 2008; 294(6): L1119-26. PubMed Abstract | Publisher Full Text

103. Kropski JA, Lawson WE, Blackwell TS: Right place, right time: the evolving role of herpesvirus infection as a "second hit" in idiopathic pulmonary fibrosis. $A m$ J Physiol Lung Cell Mol Physiol. 2012; 302(5): L441-4. PubMed Abstract | Publisher Full Text | Free Full Text

104. Egan JJ, Adamali HI, Lok SS, et al.: Ganciclovir antiviral therapy in advanced idiopathic pulmonary fibrosis: an open pilot study. Pulm Med. 2011; 2011 240805.

PubMed Abstract | Publisher Full Text | Free Full Text

105. F Jolly L, Stavrou A, Vanderstoken G, et al:: Influenza promotes collagen deposition via $\alpha v \beta 6$ integrin-mediated transforming growth factor $\beta$ activation. J Biol Chem. 2014; 289(51): 35246-63.

PubMed Abstract | Publisher Full Text | Free Full Text | F1000 Recommendation

106. Molyneaux PL, Cox MJ, Willis-Owen SA, et al:: The role of bacteria in the pathogenesis and progression of idiopathic pulmonary fibrosis. Am J Respir Crit Care Med. 2014; 190(8): 906-13. PubMed Abstract | Publisher Full Text | Free Full Text

107. F Shulgina L, Cahn AP, Chilvers ER, et al.: Treating idiopathic pulmonary fibrosis with the addition of co-trimoxazole: a randomised controlled trial. Thorax. 2013; 68(2): 155-62.

PubMed Abstract | Publisher Full Text | F1000 Recommendation 


\section{Open Peer Review}

\section{Current Peer Review Status:}

\section{Editorial Note on the Review Process}

Faculty Reviews are review articles written by the prestigious Members of Faculty Opinions. The articles are commissioned and peer reviewed before publication to ensure that the final, published version is comprehensive and accessible. The reviewers who approved the final version are listed with their names and affiliations.

\section{The reviewers who approved this article are:}

\section{Version 1}

\section{Simon P Hart}

Centre for Cardiovascular and Metabolic Research, Hull York Medical School, Cottingham, UK Competing Interests: No competing interests were disclosed.

\section{Paul W Noble}

Department of Medicine, Cedars Sinai Medical Center, Los Angeles, CA, USA

Competing Interests: No competing interests were disclosed.

The benefits of publishing with F1000Research:

- Your article is published within days, with no editorial bias

- You can publish traditional articles, null/negative results, case reports, data notes and more

- The peer review process is transparent and collaborative

- Your article is indexed in PubMed after passing peer review

- Dedicated customer support at every stage

For pre-submission enquiries, contact research@f1000.com 